\title{
Investigating the Determinants of Shariah-Compliant Firms Profitability in Indonesia: Does COVID-19 Play an Essential Role?
}

\author{
Mohammad Bintang Pamuncak ${ }^{1}$, Arland Pratama Wijaya ${ }^{2}$ \\ ${ }^{1}$ Fakultas Ekonomi dan Bisnis Syariah, Institut Agama Islam Tazkia, Jl. Ir. H. Djuanda No.78, Sentul City, \\ Bogor, Indonesia, mbintangp@tazkia.ac.id. \\ ${ }^{1}$ Fakultas Ekonomi dan Bisnis Syariah, Institut Agama Islam Tazkia, Jl. Ir. H. Djuanda No.78, Sentul City, \\ Bogor, Indonesia, arlandpratamawijaya@gmail.com.
}

\begin{abstract}
This study aims to seek the determinants of sharia-compliant firm profitability in Indonesian JII listed companies. This study employed Data Panel regression analysis using the 12 most consistent companies who listed in the JII during the period of Q1 2015 to Q4 2020 where in total, there are 282 number of observation. The study found that both firm-internal and firm-external variabels are significant in determining firm profitability on at least one model of data panel regression. COVID-19 and GDP used to measure the impact of firm-external variables, while working capital, debt to equity ratio, and quick ratio used to determine firm-internal variable. Further studies are required to observe the longer period of COVID-19 impact on sharia-compliant firm profitability.
\end{abstract}

Keywords: COVID-19, firm, profitability, sharia-compliant.

\begin{abstract}
Abstrak. Penelitian ini bertujuan untuk mengetahui determinan atau faktor-faktor yang memengaruhi profitabilitas perusahaan yang telah memenuhi kepatuhan syariah dan terindeks ke dalam Jakarta Islamic Idex (JII). Penelitian ini menggunakan regresi data panel, dengan menggunakan 12 perusahaan yang paling konsisten terindeks dalan JII pada periode Q1 2015 sampai dengan Q4 2020, di mana secara total terdapat 282 observasi. Penelitian ini menemukan bahwa kedua faktor baik internal maupun eksternal berpengaruh signifikan dalam kepada profitabilitas perusahaan, setidaknya dalam satu model regresi data panel. Variabel COVID-19 dan PDB digunakan sebagai variabel eksternal dan variablel working capital, debt to equity ratio, dan quick ratio digunakan sebagai variabel internal. Studi lebih lanjut dibutuhkan untuk mengamati variabel dampak COVID-19 terhadap profitabilitas perusahaan.
\end{abstract}

Kata kunci: COVID-19, kepatuhan syariah, perusahaan, profitabilitas.

\section{INTRODUCTION}

Alarussi and Alhaderi (2018) stated that in order to maintain competitiveness and sustainability of a company, it is important to realize the determinant factors of firm profitability. In particular, during the time of crisis, it is essential to calculate all risks that might contribute to a harmful situation for the firm profitability. Therefore, firm managers could formulate the best strategies considering risks that may appear from both firm-internal and firm-external factors in order to maintain or even boost their firm-profitability.

In identifying the determinants of firms profitability, numerous study has been done by many scholars (Alarussi and Alhaderi, 2018). We note, Salike and Ao (2018) which seek the impact of internal and external factors on the profitability of 12 banks in Asia during the period of 2001-2015. The study stated that the external factor which measured by macroeconomic indicator has the most significant influence on the banks perfomance. Contrastly, Ali and Puah (2019) stated that financial crisis which also indicates the external factor is statistically insignificant to the banks performance in Pakistan.

Furthermore, we also note Yazdanfar (2013) who observed the factors affecting micro-firm profitability in Swedia. Tyagi and Nauriyal (2017) who observed the factors affecting micro-firm profitability in India. Meanwhile, Asimakopoulos et al. (2009) observed determinant factors of firmprofitability listed in Greece stock' market. Alarussi and Alhaderi (2018), seek the determinant factors 
of firm-profitability in Malaysia, and Nanda and Panda (2018) observed the determinants of firm profiability listed on stock market in India. Nevertheless, despite it numerous research, one thing that we also note that those previous studies show inconsistent findings. Thus, accoruding Alarussi and Alhaderi (2018), it implies that there is still a gap to determine the factors that affect firm profitability.

On the other hand Hassan et al. (2020) stated that the research on shariah-compliant firm that listed in financial market has not been done by many scholars comparing to the research on Islamic banking and finance. We note only Alsharari and Alhmoud (2019) who specifically discussing the issue of factors affecting shariah-compliant firm profitability in Jordan. However, Alsharari and Alhmoud (2019) did not consider external factor that could determine shariah-compliant firm profitability.

Furthermore, Alshater et al. (2020) stated that one of the research theme in Islamic economic and finance that might be explored further is to observed the impact of global COVID-19 pandemic on the performance of shariah-compliant firm listed in stock market. This is interesting as we all know that as earlier as the fourth quarter of 2019 , global economic condition entering the uncertainty due to the spread of COVID-19. For instance, it hits Indonesian economic growth, where it is slowing down in 2020 to $-2.07 \%$ (BPS, 2020). Therefore, based on that information, this study attempts to investigate both internal and external factors that could affect the shariah-compliant firm-profitability as previous studies such as Alsharari and Alhmoud (2019) and Alarussi and Alhaderi (2018) did not include the external factor on their observation. However, this study is limited to used some variables that most commonly used by previous study. For instance, Return on asset (RoA) is used for the measurement of profitability, working capital turnover for the measurement of working capital, debt-to-equity ratio for the measurement of leverage, and quick ratio for indicating liquidity.

\section{LITERATURE REVIEW}

\section{Working Capital and Profitability}

Working capital according to Kasmir (2013) refers to the difference between firm asset such as cash, account receiveable, and inventories to firm liability such as account payable. In other word, it can also be defined as firm responsibilities to map the company' operation or produce in both short term and long term. Supriatna and Wardana (2020) stated that working capital is a number of money that put by firm in the most liquid form of investment such as cash, checking account and others. In sum, working capital may refer to managers strategy to optimize firm-profitability through keeping and handling correctly the cash conversion cycle and account receiveable (Lazaridis and Tryfonidis, 2006).

With regard to the role of working capital to firm profitability, it is shown incosistent result. Chowdhury and Amin (2007), Alipour (2011), Malik (2011), Burja (2011), and Alarussi and Alhaderi (2018) shows that working capital has a positive and significant relationship to firm-profitability. Meaning that the managers can optimally maximize the working capital, meanwhile, Dong and $\mathrm{Su}$ (2010) show a contrast result where the study found that working capital has negative relationship to firm-profitability. Or in other words, managers could not maximize the firm-profitability through working capital.

Therefore, as it shows inconsistent result, it is interesting to know the effect of working capital to shariah-compliant firm profitabiliy in Indonesia with the hypotheses are as follow:

$\mathrm{H}_{1}=$ Working capital turnover is significantly associated to the shariah-compliant firm profitability.

$\mathrm{H}_{2}=$ Working capital turnover isn't significantly associated to the shariah-compliant firm profitability.

\section{Leverage and profitability}

Leverage refers to the stratetegy of investment by firm in maximizing return or profit by combining structure of capital. According to Kasmir (2013), highly leveraged firm might be driven the company 
to face both highly risk to bankruptcy and also potential to gain high return. It is because, highly leveraged firm uses debt more as source of capital which is increasing firm' risk where at the same time the debt used is also essential to be referred as source of capital.

As the debt might contribute to higher risk, financial service authorities (OJK) of Indonesia set the highest leverage percentage for shariah-compliant firm listed in financial market by $45 \%$. It is particularly higher percentage comparing to the requirement for company listed in Dow Jones Islamic Market (DJIM) where according to Hanafi (2011) the authorities set the firm who listed in the Dow Jones Islamic Market (DJIM) must not exceed 33\% of debt as their source of capital.

Nevertheless, despite the differences from both financial market, leverage oftenly used by many scholars to determined factors affecting firm profitability. For instance Yazdanfar (2013) who stated companies using large borrowings will face higher risk. Boadi et al. (2013) stated that there is positive relationship and significant relationship between leverage and profitability. Meaning that managers could maximize the capital structure of their company to gain maximum profitability. Meanwhile, in contrast, Alarussi and Alhaderi (2018) shows that there is negative relationship between leverage and profitability or in other words, managers has failed to maximize profitability through leverage ratio. As the inconsistent result happens, it is interesting to investigate the impact of leverage on the firm profitabilities. Hypotheses are as follow:

$\mathrm{H}_{3}=$ Leverage is significantly associated to the shariah-compliant firm profitability.

$\mathrm{H}_{4}=$ Leverage isn't significantly associated to the shariah-compliant firm profitability.

\section{Liquidity and Profitability}

Liquidity refer to firm ability in converting an asset to cash quickly. Futher, liquidity is also refer to the firm ability to pay off its short-term obligations. There are numerous measurement to measure firm liquidity such as current ratio, quick ratio, can cash ratio (Alarussi and Alhaderi, 2018). If a company maintain its liquidity at a higher level than its short-term obligation, it will impact to the decrease of firm-profitability as the extra fund held up as cash or liquid assets will become an idle asset for investment (Bhayani, 2010).

Numerous scholar has also tried to seek the impact of firm liquidity to firm profitability. Bhayani (2010) attempt to find the determinant of cement firm profitability in India and found that the is a positive relationship between firm liquidity and firm profitability. Meanwhile Eljelly (2004) found a negative relationship between profitability and liquidity indicators. On the other hand, a more recent study, Alarussi and Alhaderi (2018) stated that there is no relationship between liquidity and firm profitability.

In respoding inconsisten result, this study employed two indicators to measure liquidity, namely quick ratio and current ratio. Hypotheses are as follow:

$\mathrm{H}_{5}=$ Quick ratio is significantly associated to the shariah-compliant firm profitability.

$\mathrm{H}_{6}=$ Quick ratio isn't significantly associated to the shariah-compliant firm profitability.

\section{External-Firm Variables and Profitability}

In investigating the determinant of firm profitability, it is important to include the external factors that could effect the firm profitability Alarussi and Alhaderi (2018). As related prevoious studies such as Alarussi and Alhaderi (2018) and Alsharari and Alhmoud (2019) did not include this variable in their observation, therefore this study attempts to fill in the gap. In fact, another studies which mainly focused in determining factors on banking sector has include external factors. We note Ali and Puah (2019) include financial crisis variable in seeking the determinant factors of bank profitability in Pakistan. Ali and Puah (2019) reveal that there is no positive and significant relationship between financial crisis variable which represented by dummy variable. Meanwhile, Orhun (2020) mentioned 
that most of the stock market across the globe has witnessed a negative impact by the existence of COVID-19, particularly in the first quarter of 2020.

On the other hand, studies such as Cyril and Singla (2020), Alharbi (2017) and Salike and Ao (2018) include macroeconomic variables such as GDP and inflation. Surprisingly, the result is inconsistent where Cyril and Singla (2021) reveal that there is no effect of external factors to firm profitabilities which indicated by macroeconomics variable such as Gross Domestic Product (GDP) and inflation. In contrast, Alharbi (2017) stated that there is a negative relationship between GDP and profitability of Islamic banking in Saudi Arabia. Meanwhile, Salike and Ao (2018) stated that external factors which measured by real GDP is the most significant factors that affect bank profitability in Asia. Therefore, to investigate the determinant firm-external factors, this study will used COVID-19 (represent the crisis indicators) and GDP. Hypotheses are as follow:

$\mathrm{H}_{7}=\mathrm{COVID}-19$ is significantly associated to the shariah-compliant firm profitability.

$\mathrm{H}_{8}=$ COVID-19 isn't significantly associated to the shariah-compliant firm profitability.

$\mathrm{H}_{9}=$ GDP is significantly associated to the shariah-compliant firm profitability.

$\mathrm{H}_{10}=$ GDP isn't significantly associated to the shariah-compliant firm profitability.

\section{Profitabilily}

In measuring the firm-profitability, numerous indicators has been used by previous studies. For instance, Return of Average Asset (ROAA) referred by Salike and Ao (2018), Net Profit Margin (NPF) referred by Tyagi and Nauriyal (2017) and Nanda and Panda (2018), and Earning per Share (EPS) referred by Alarussi and Alhaderi (2018). But most of previous studies referred to the Return on Asset (RoA) as the measurement of firm-profitability, for instance Asimakopoulos et al. (2009), Yazdanfar (2013), Nanda and Panda (2018), Ali and Puah (2019), and Alsharari and Alhmoud (2019). Therefore, this study employed the RoA as measurement of firm-profitability.

\section{METHOD}

\section{Population, Sample, Sample Size}

This study utilized secondary data which is quarterly financial report that collected from official webistes of each sample. The population in this study is all company listed in the Jakarta Islamic Index (JII) during the period of Q1 2015 to Q4 2020, wherein total there are 50 companies who listed in the index at least once. To determine the company who listed in the index, the Indonesian stock market authority made a regular evaluation twice a year. Table 1 shows the list of firm which has been listed in the JII during the period.

To determie the size of sample, this study employed a purposive sampling with criteria: a) The financial statement and annual report is accesible online and b) The sample is the most consistent company which listed in the JII during the period of sample. There are 12 companies who has been consistently listed in the JII during the period. Table 2 below shows the list of firm which had been utilized as a sample in this study. 
Table 1 List of JII indexed firm 2015-2020

\begin{tabular}{cccccc}
\hline No & Firm initial & $\begin{array}{c}\text { Freq. Listed in the JII } \\
\text { during 2015-2020 }\end{array}$ & No & $\begin{array}{c}\text { Firm } \\
\text { Initial }\end{array}$ & $\begin{array}{c}\text { Freq. Listed in the JII } \\
\text { during 2015-2020 }\end{array}$ \\
\hline 1 & AALI & 4 & 26 & TPIA & 6 \\
2 & ADRO & 10 & 27 & UNTR & 10 \\
3 & AKRA & 10 & 28 & UNVR & 10 \\
4 & ANTM & 9 & 29 & WIKA & 10 \\
5 & ASII & 10 & 30 & WSKT & 5 \\
6 & BSDE & 9 & 31 & INTP & 10 \\
7 & CTRA & 7 & 32 & BRPT & 6 \\
8 & EXCL & 7 & 33 & SCMA & 6 \\
9 & ICBP & 10 & 34 & ITMG & 6 \\
10 & INCO & 10 & 35 & CPIN & 5 \\
11 & INDF & 10 & 36 & JSMR & 5 \\
12 & KLBF & 10 & 37 & WSBP & 4 \\
13 & LPKR & 6 & 38 & INDY & 3 \\
14 & LPPF & 8 & 39 & BTPS & 3 \\
15 & LSIP & 5 & 40 & ERAA & 3 \\
16 & MYRX & 3 & 41 & JPFA & 3 \\
17 & PGAS & 9 & 42 & MNCN & 3 \\
18 & PPRO & 1 & 43 & SILO & 3 \\
19 & PTBA & 9 & 44 & MIKA & 2 \\
20 & PTPP & 9 & 45 & MPPA & 2 \\
21 & PWON & 5 & 46 & ASRI & 2 \\
22 & SMGR & 9 & 47 & ACES & 1 \\
23 & SMRA & 7 & 48 & MDKA & 1 \\
24 & SSMS & 4 & ADHI & 1 \\
25 & TLKM & 10 & 50 & BMTR & 1 \\
\hline SOHA & 59 & & \\
\hline
\end{tabular}

Source: IDX Statistics, 2020 (modified by author)

Table 2 List of sample

\begin{tabular}{cccccc}
\hline No & $\begin{array}{c}\text { Firm } \\
\text { initial }\end{array}$ & $\begin{array}{c}\text { Freq. Listed in the JII } \\
\text { during 2015-2020 }\end{array}$ & No & $\begin{array}{c}\text { Firm } \\
\text { initial }\end{array}$ & $\begin{array}{c}\text { Freq. Listed in the JII } \\
\text { during 2015-2020 }\end{array}$ \\
\hline 1 & ADRO & 10 & 7 & KLBF & 10 \\
2 & AKRA & 10 & 8 & TLKM & 10 \\
3 & ASII & 10 & 9 & UNTR & 10 \\
4 & ICBP & 10 & 10 & UNVR & 10 \\
5 & INCO & 10 & 11 & WIKA & 10 \\
6 & INDF & 10 & 12 & INTP & 10 \\
\hline
\end{tabular}

\section{Variable Description and Dateset}

As for the dataset for firm-internal variables, this study will use financial indicators which mostly indicated by the financial ratio such as working capital, debt-equity ratio, and quick ratio. Further, for the firm-external variable, this study will use dummy variable to measure the effect of COVID-19 and GDP (Current expenditure, IDR). This Table 3 below simplified the variable description: 
Table 3 Variable description

\begin{tabular}{|c|c|c|c|c|}
\hline & Variable & Indicator & Reference & $\begin{array}{c}\text { Expected } \\
\text { Signs } \\
\end{array}$ \\
\hline \multirow[t]{3}{*}{$\begin{array}{l}\text { Internal } \\
\text { Determinants }\end{array}$} & $\begin{array}{l}\text { Working } \\
\text { capital }\end{array}$ & $\begin{array}{l}\text { Working capital } \\
\text { ratio (WCT) }\end{array}$ & $\begin{array}{l}\text { Chowdhury and Amin (2007), } \\
\text { Alipour (2011), Malik (2011), } \\
\text { Burja (2011), Alarussi and } \\
\text { Alhaderi (2018), and Dong and } \\
\text { Su (2010). }\end{array}$ & $+/-$ \\
\hline & Leverage & $\begin{array}{l}\text { Debt-equity } \\
\text { ratio (DER) }\end{array}$ & $\begin{array}{l}\text { Yazdanfar (2013), Boadi et al } \\
\text { (2013), Dalci (2018), and } \\
\text { Alarussi and Alhaderi (2018) }\end{array}$ & $+/-$ \\
\hline & Liquidity & $\begin{array}{ll}\text { Quick } & \text { ratio } \\
\text { (QR) } & \end{array}$ & $\begin{array}{l}\text { Bhayani (2010), Eljelly (2004), } \\
\text { and Alarussi and Alhaderi } \\
\text { (2018) }\end{array}$ & $+/-$ \\
\hline \multirow[t]{2}{*}{$\begin{array}{l}\text { External } \\
\text { Determinants }\end{array}$} & $\begin{array}{l}\text { Covid-19 } \\
\text { (Measuring } \\
\text { crisis) }\end{array}$ & $\begin{array}{l}\text { Dummy } \\
\text { variable } \\
\text { (COVID-19) } \\
0=\text { Pre-covid19 } \\
1=\text { Post-covid19 }\end{array}$ & Ali and Puah (2019) & - \\
\hline & $\begin{array}{l}\text { GDP (Current } \\
\text { expenditure, } \\
\text { IDR) }\end{array}$ & LnGDP & $\begin{array}{l}\text { Cyril and Singla (2020), Alharbi } \\
\text { (2017), and Salike and Ao } \\
\text { (2018). }\end{array}$ & + \\
\hline $\begin{array}{l}\text { Independent } \\
\text { Variable }\end{array}$ & Profitability & $\begin{array}{l}\text { Return on Asset } \\
\text { (ROA) }\end{array}$ & $\begin{array}{l}\text { Asimakopoulos et al. (2009), } \\
\text { Yazdanfar (2013), Nanda and } \\
\text { Panda (2018), Ali and Puah } \\
\text { (2019), and Alsharari and } \\
\text { Alhmoud (2019) }\end{array}$ & \\
\hline
\end{tabular}

\section{Methodology}

Fundamentally this study focus on investigating the determinant of shariah-compliant firmprofitability listed in the JII. In order to achieve that objectives, this study employed an econometric approach which is panel data regression following the steps that has employed by previous studies such as Alarussi and Alhaderi (2018), Asimakopoulos et al. (2009), Ali and Puah (2019), and Salike and Ao (2018). The data panel analysis is a model that combine the cross-section and time series data.

The data panel regression has several models. The models are pooled least square (PLS model) (1), fixed effect model (FEM) (2), and random effect model (REM) (3). To know the best model, there are several test that must be done which are a) Chow test, b) Hausman test and c) LM test (Wooldridge, 2001; Pindyck and Rubinfeld, 1998).

The general model of this study is specified in this equation below:

$$
\mathrm{RoA}_{\mathrm{it}}=\beta_{0}+\beta_{1} \mathrm{WCT}_{\mathrm{it}}+\beta_{2} \mathrm{DER}_{\mathrm{it}}+\beta_{3} \mathrm{QR}_{\mathrm{it}}+\beta_{4} \mathrm{COVIID} 19_{\mathrm{it}}+\beta_{5} \mathrm{LnGDP}_{\mathrm{it}} \varepsilon_{\mathrm{f}}
$$

Where:

$\mathrm{it}=$ for number of firm ' $\mathrm{i}$ ' and for quarterly ' $\mathrm{t}$ '

$\mathrm{RoA}_{\mathrm{it}}=$ Return on Asset of firm

$\beta_{0}=$ Constant

$\mathrm{WCT}_{\mathrm{it}}=$ Working capital ratio of firm

$\mathrm{DER}_{\mathrm{it}}=$ Debt-Equity ratio of firm

$\mathrm{QR}_{\mathrm{it}}=$ Quick ratio of firm

COVID-19 $=$ A dummy variable which equals one for post-Covid-19 and zero is otherwise

LnGDP $_{\text {it }}=$ LnGross Domestic Product (Current expenditure, IDR) 


\section{RESULTS AND DISCUSSION}

\section{Empirical Result}

Overall, three out of four firm-internal variable are decreasing after COVID-19 period. It is noted that the average of RoA is decreasing from 6.575 to 5.975. WCT is also decreasing from 1.968 to 1.413 , while QR is decreasing from 1.796 to 1.605 during the same period. It is noted that only DER which increased during the same period from 89.182 to 109.31. summary statistics of the data is shown in this Table 4. Furthermore, the summary of GDP developement is shown in the graph 1 where it shows that the GDP is growing quite constantly during the period Q1_2015 to Q3_2019 while it is decreasing significantly in Q4_2019 and fluctuate during the rest of period.

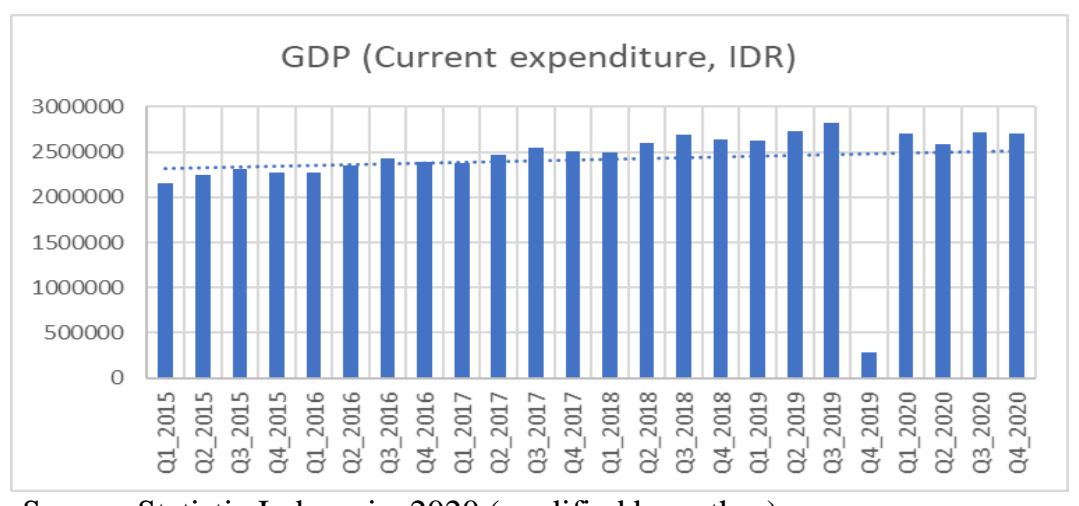

Source: Statistic Indonesia, 2020 (modified by author)

Figure 1 GDP (Current expenditure, IDR)

Table 4 Summary statistics of test variables (internal factors)

\begin{tabular}{|c|c|c|c|c|c|c|c|c|c|}
\hline \multirow{2}{*}{$\begin{array}{l}\text { Panel: By } \\
\text { Quarter }\end{array}$} & \multirow[b]{2}{*}{$\mathbf{n}$} & \multicolumn{2}{|c|}{ (Y) ROA } & \multicolumn{2}{|c|}{ WCT } & \multicolumn{2}{|c|}{ DER } & \multicolumn{2}{|c|}{ QR } \\
\hline & & $\begin{array}{c}\text { Before c-19 } \\
\text { (Mean) }\end{array}$ & $\begin{array}{c}\text { After c-19 } \\
\text { (Mean) }\end{array}$ & $\begin{array}{c}\text { Before c-19 } \\
\text { (Mean) }\end{array}$ & $\begin{array}{c}\text { After c-19 } \\
\text { (Mean) }\end{array}$ & $\begin{array}{c}\text { Before c-19 } \\
\text { (Mean) }\end{array}$ & $\begin{array}{c}\text { After c-19 } \\
\text { (Mean) }\end{array}$ & $\begin{array}{c}\text { Before c-19 } \\
\text { (Mean) }\end{array}$ & $\begin{array}{c}\text { After c-19 } \\
\text { (Mean) }\end{array}$ \\
\hline Q1_2015 & 12 & 3.00 & & 0.33 & & 86.365 & & 1.936 & \\
\hline Q2_2015 & 11 & 5.24 & & 1.89 & & 95.599 & & 1.574 & \\
\hline Q3_2015 & 11 & 7.01 & & 1.91 & & 89.054 & & 1.708 & \\
\hline Q4_2015 & 11 & 9.28 & & 2.90 & & 90.054 & & 1.726 & \\
\hline Q1_2016 & 12 & 2.55 & & 0.47 & & 85.497 & & 2.050 & \\
\hline Q2_2016 & 12 & 5.49 & & 1.84 & & 98.664 & & 1.962 & \\
\hline Q3_2016 & 12 & 8.27 & & 2.13 & & 88.020 & & 2.121 & \\
\hline Q4_2016 & 12 & 10.94 & & 3.81 & & 81.886 & & 1.883 & \\
\hline Q1_2017 & 12 & 4.95 & & 0.73 & & 76.962 & & 2.051 & \\
\hline Q2_2017 & 12 & 5.64 & & 3.79 & & 93.621 & & 1.797 & \\
\hline Q3_2017 & 12 & 8.41 & & 3.10 & & 83.759 & & 1.957 & \\
\hline Q4_2017 & 12 & 10.63 & & 7.27 & & 89.213 & & 1.910 & \\
\hline Q1_2018 & 12 & 2.90 & & 0.72 & & 84.582 & & 2.017 & \\
\hline Q2_2018 & 12 & 5.33 & & 0.80 & & 102.301 & & 1.642 & \\
\hline Q3_2018 & 12 & 8.69 & & -1.46 & & 89.104 & & 1.623 & \\
\hline Q4_2018 & 12 & 11.32 & & 2.42 & & 86.994 & & 1.528 & \\
\hline Q1_2019 & 12 & 2.47 & & 1.75 & & 81.531 & & 1.591 & \\
\hline Q2_2019 & 12 & 5.08 & & 1.01 & & 101.701 & & 1.503 & \\
\hline Q3_2019 & 12 & 7.73 & & 1.88 & & 89.569 & & 1.549 & \\
\hline Q4_2019 & 12 & & 10.23 & & 2.76 & & 95.532 & & 1.656 \\
\hline Q1_2020 & 12 & & 2.61 & & 0.34 & & 90.033 & & 1.712 \\
\hline Q2_2020 & 12 & & 4.77 & & -0.68 & & 84.502 & & 1.750 \\
\hline Q3_2020 & 12 & & 6.11 & & 2.85 & & 97.540 & & 1.6599 \\
\hline Q4_2020 & 9 & & 6.16 & & 1.80 & & 69.611 & & 1.248 \\
\hline Total & 282 & 6.575 & 5.975 & 1.968 & 1.413 & 89.182 & 109.31 & 1.796 & 1.605 \\
\hline Median (AII) & \multicolumn{3}{|c|}{4.49} & \multicolumn{2}{|c|}{1.76} & \multicolumn{2}{|c|}{77.25} & \multicolumn{2}{|c|}{1.41} \\
\hline Std Dev (All) & \multicolumn{3}{|c|}{7.162} & \multicolumn{2}{|c|}{7.469} & \multicolumn{2}{|c|}{71.269} & \multicolumn{2}{|c|}{1.063} \\
\hline Variance (AII) & \multicolumn{3}{|c|}{51.487} & \multicolumn{2}{|c|}{55.987} & \multicolumn{2}{|c|}{5097.45} & \multicolumn{2}{|c|}{1.135} \\
\hline
\end{tabular}

Note: The displayed data is in ratio 
Table 5 Panel data regression results

\begin{tabular}{|c|c|c|c|c|c|c|c|c|}
\hline \multirow[t]{2}{*}{ Models } & \multicolumn{6}{|c|}{ Variables } & \multirow{2}{*}{$\begin{array}{c}\text { F/Wald } \\
\text { Test }\end{array}$} & \multirow[t]{2}{*}{$\mathbf{R}^{2}$} \\
\hline & Constant & WCT & DER & QR & COVID19 & GDP & & \\
\hline \multirow[t]{2}{*}{ PLS (2) } & $40.285^{* * *}$ & $-.3034^{* * * *}$ & $.0133^{*}$ & $-1.381^{* * *}$ & -1.577 & $-2.154^{* * *}$ & $15.62^{* * *}$ & 0.2206 \\
\hline & $(0.003)$ & $(0.000)$ & $(0.065)$ & $(0.004)$ & $(0.121)$ & $(0.018)$ & $(0.000)$ & \\
\hline \multirow[t]{2}{*}{ FEM (3) } & $32.51 * * *$ & .01819 & .0118 & .5535 & -1.8996 & $-1.899 * * *$ & $2.51 * *$ & 0.0184 \\
\hline & $(0.000)$ & $(0.655)$ & $(0.290)$ & $(0.380)$ & $(0.116)$ & $(0.002)$ & $(0.0305)$ & \\
\hline \multirow[t]{2}{*}{ REM (4) } & $33.946^{* * *}$ & -.0384 & $.0208^{* *}$ & -.2099 & $-1.264^{*}$ & $-1.948^{* * * *}$ & $17.11^{* * * *}$ & 0.1445 \\
\hline & $(0.001)$ & $(0.365)$ & $(0.022)$ & $(0.710)$ & $(0.087)$ & $(0.003)$ & $(0.0043)$ & \\
\hline GLS (5) & $\begin{array}{l}40.285^{\text {**** }} \\
(0.002)\end{array}$ & $\begin{array}{l}-.3034^{* * * *} \\
(0.000)\end{array}$ & $\begin{array}{l}.0133^{*} \\
6062)\end{array}$ & $\begin{array}{l}-1.381^{* * * *} \\
(0.004)\end{array}$ & $\begin{array}{l}-1.577 \\
(0.116\end{array}$ & $-2.154^{* *}$ & $\begin{array}{l}79.82^{* * * *} \\
(0.000)\end{array}$ & 0.7976 \\
\hline \multirow{2}{*}{\multicolumn{7}{|c|}{ Hausman Test }} & -6.91 & \\
\hline & & & & & & & (0.999) & \\
\hline \multirow{2}{*}{\multicolumn{7}{|c|}{ LM Test }} & $585.06^{* * *}$ & \\
\hline & & & & & & & $(0.000)$ & \\
\hline \multirow{2}{*}{\multicolumn{7}{|c|}{ Lawley test for autocorrelation }} & $170.04 * * *$ & \\
\hline & & & & & & & $(0.000)$ & \\
\hline \multirow{2}{*}{\multicolumn{7}{|c|}{ Doornik-Hansen normality test }} & $5127.463^{* * * *}$ & \\
\hline & & & & & & & $(0.000)$ & \\
\hline \multicolumn{7}{|c|}{ Breusch-Pagan/Cook-Weisberg heteroskedasticy test } & $\begin{array}{l}62.33^{* * * *} \\
(0.000)\end{array}$ & \\
\hline
\end{tabular}

* Significant on alpha $10 \%$

0 p-value

** Significant on alpha $5 \%$

*** Significant on alpha $1 \%$

Table 5 displays the result of panel data regression and classical assumption test. The classical assumption test result says that the data in this study is distributed normally $(0.000)$, does not suffer the autocorrelation (0.000), nor heteroskedasticity (0.000). Further, Table 5 also displays the result of all panel data regression models such as PLS, FEM, REM, and GLS. In general, the PLS and GLS show similar result where four variables except COVID-19 variables are significant at different significant level. Meanwhile, the result of FEM model stated that GDP is the only variable who has significant effect to the shariah-compliant firm profitability at alpha 10\% (0.1). And the result of REM model stated that DER, COVID-19, and GDP variables are significant to the sharia-compliant firmprofitability also at different significant level. Furthermore, with regard to determine the best model, the statistic result of hausman test and LM test stated that the best model in this study is PLS model as hausman test show insignificant result at any different level while LM test show that it is significant at $1 \%$ significant level. Moreover, as many as $22.06 \%$ variation in shariah-compliant firm-profitability is explained by independent variables in the PLS model. Among those significant independent variables in the PLS model, the working capital, is the most significant variable both statistically (at $1 \%$ level) and economically $(-30.34 \%)$.

\section{Discussion}

\section{Working capital and profitability}

The PLS and GLS model shows that WCT variable is significant on alpha $1 \%(0.000)$ to the shariacompliant firm profitability with a negative relationship, where partially the increase of WCT is associated to the decrease of $30.34 \%$ of sharia-compliant firm profitability in which here is measured by RoA. Meanwhile, FEM and REM model show that working capital is insignificant to firmprofitability. The relation beween WCT and profitability in this study is consistent with Lazaridis and Tryfonidis (2006), Gill et al. (2010) and Dong and Su (2010) where they stated that working capital has significant and negative relationship to firm-profitability.

This findings imply some implications. First, as it shows that there is negative relationship between working capital and profitability, this findings shows that managers of sharia-compliant firm listed in JII could not maximize the firm-profitability through working capital during the period of Q1_2015 to Q4_2020. Second, managers are urged to handle their company cash and account recieveable accordingly in order to boost their company profitability. 


\section{Leverage and profitability}

The PLS, REM, GLS model shows that DER variable is significant on alpha 5\% (0.05) and alpha $10 \%(0.10)$ to the sharia-compliant firm profitability with a positive relationship, where partially the increase of DER is associated to the increase of $1 \%$ to $2 \%$ of sharia-compliant firm profitability which is measured by RoA. Meanwhile, FEM model show that working capital is insignificant to firmprofitability. The relation beween WCT and profitability in this study is consistent with Boadi et al. (2013) and Dalci (2018) where they stated that working capital has significant and relationship to firm-profitability.

This findings imply some implications. First, managers of shariah-compliants firm listed in JII has succesfully minimizing the risk and maximizing the profitability from their capital structure choice where in average the debt-equity ratio (DER) of listed sample is more than $80 \%$ as shown the the Table 4 above. Second, this result confirm a classic Modigliani-Miller (MM) theorem (1958) on cost of capital of a firm where it mostly contributed by the debt-equity ratio (DER). Third, this findings also shows that most of firms who listed in the JII still maximize their DER above the requirement levet that set by the authorities even it is resulting to the betterment of their profitability, but still it does not comply with the shariah law. Therefore, there must be some solutions offered by the authorities in regards to handle this matter, as this is essential for the sustainability of shariahcompliant firm.

\section{Liquidity and profitability}

The PLS and GLS model shows that QR variable is significant on alpha 1\% (0.000) to the shariacompliant firm profitability with a negative relationship, where partially the increase of $\mathrm{QR}$ is associated to the decrease of $13.81 \%$ of sharia-compliant firm profitability which is measured by RoA. Meanwhile, FEM and REM model show that working capital is insignificant to firmprofitability. The relation beween QR and profitability in this study is consistent with Eljelly (2004) where it stated that firm-liquidity has significant and negative relationship to firm-profitability.

This finding imply some implications. First, shariah-compliant firm that listed in the JII are having an excess fund and it leads to the decrease of their profitability since their excess fund is not utilized to perform another investment activity. Second, managers are urged to utilize their excess fund to an investment that would lead to the improvment of firm-profitability. Third, the higher level of liquidity might also inform that managers are holding up their cash on purpose. However as this findings stated that the relation between liquidity and profitability is negative, therefore managers could change their strategies accordingly.

\section{External-firm variables and profitability}

In investigating the determinant of firm profitability, this study also include firm-external factros. The firm-external factors that include in this study is COVID-19 as a measurement of crisis and Gross Domestic Product (GDP). The PLS, FEM, REM, and GLS model shows that GDP is significant on alpha $1 \%(0.000)$ and alpha $5 \%(0.05)$ to the sharia-compliant firm profitability with a negative relationship, where partially the increase of GDP is associated to the decrease of $1 \%$ to $2 \%$ of shariacompliant firm profitability which is measured by RoA. These findings is consistent with Alharbi (2017) where they stated that surprisingly there is a negative relationship between GDP and firmprofitability.

This unfamous result may implied some implication. First, shariah-compliant firms that listed in the JII are more sensitive to the changing of GDP. Further, these findings may reflected from the sample criteria where most of the firm that utilized as sample in this study are operating in the real sector such as construction, cement, telecommunication, pharmacy, food and beverages, and energy industry. Second, these findings also urge managers to reflect and consider macroeconomic factor such as GDP to formulate the correct strategy in maximizing their profit. Third, these findings also strengthen the role of government to create such a proper environment for industry to condunt their businesses. 
Further, among the four data panel models, the COVID-19 is significant on REM model on alpha $10 \%(0.10)$ to the sharia-compliant firm profitability with a negative relationship, where partially the increase of COVID-19 is associated to the decrease of $1.26 \%$ of sharia-compliant firm profitability which is measured by RoA. This result is inconsistent with Ali and Puah (2019) where they stated that there is no relationship between crisis and profitability. However, this result support our hypothesis where COVID-19 is negatively associated to the firm-profitability.

These findings also imply some implication. First, shariah-compliant firms that listed in the JII are more sensitive to the changing of GDP. In specific the shariah-compliant firm that used as sample in this study where most of them are operating in the real sector. Second, that managers must also include the COVID-19 factors to formulate their strategies to get maximum profit. And third, these findings also strengthen the role of government to create such a proper environment for industry to condunt their businesses particularly during the time of crisis such what is happening at the moment. However, these findings must also look carefully as it shows that COVID-19 variable is significant only on the REM model. Therefore, future study is required to investigate more deeply the relation between COVID-19 and shariah-compliant firm profitability.

\section{CONCLUSION}

This study has successfully found the determinant of shariah-compliant firm-profitability with regards to the firm-internal and firm-external factors where all of the variables are significant on at least one model of data panel regression. Or in other words the variables that tested in this study are considered as determinant factors of sharia-compliant firm-profitability listed in the JII. The empirical result of this study implies some implications where most of the implication is depending on the manager behavior and firm goals, for instance with respect to the negative relation between liquidity and firmprofitability. Further implication is related to the firm-external variable such as GDP which stated that shariah-compliant firm is more sensitive to the change of GDP during the period of the study. Lastly, future studies are required to investigate more deeply the relation between Covid-19 and shariahcompliant firm profitability as our finding only supported by one model of panel data regression.

\section{REFERENCES}

Alarussi, A. S. \& Alhaderi, S. M. (2018). Factors affecting profitability in Malaysia. Journal of Economic Studies, 45(3).

Alharbi, A. T. (2017). Determinants of Islamic banks' profitability: International evidence. International Journal of Islamic and Middle Eastern, 10(3).

Ali, M., \& Puah, C. H. (2019). The internal determinants of bank profitability and stability: An insight from banking sector of Pakistan. Management Research Review, 42(1).

Alipour, M. (2011). Working capital management and corporate profitability: Evidence from Iran. World applied sciences journal, 12(7), 1093-1099.

Alsharari, N. M., \& Alhmoud, T. R. (2019). The determinants of profitability in Sharia-compliant corporations: evidence from Jordan. Journal of Islamic Accounting and Business Research, 10(4).

Alshater, M. M., Hassan, M. K., Khan, A., \& Saba, I. (2020). Influential and intellectual structure of Islamic finance: a bibliometric review. International Journal of Islamic and Middle Eastern Finance and Management.

Asimakopoulos, I., Samitas, A. \& Papadogonas, T. (2009). Firm specific and economy wide determinants of firm profitability: Greek evidence using panel data. Managerial Finance, 35(11), 930-939.

Bhayani, S. J. (2010). Determinants of profitability in Indian cement industry: An economic analysis. South Asian Journal of Management, 17(4), 6-20.

Boadi, E. K., Antwi, S. \& Lartey, V. C. (2013). Determinants of profitability of insurance firms in Ghana. International Journal of Business and Social Research, 3(3), 43-50. 
Burja, C. (2011). Factors influencing the company's profitability. Annales Universitatis Apulensis Series Oeconomica, 13(2), 215-224.

Chowdhury, A. \& Amin, M. (2007). Working capital management practiced in Pharmaceutical companies in Dhaka stock exchange. BRAC University Journal, 4(2), 75-86.

Cyril, E. J., \& Singla, H. K. (2020). Comparative analysis of profitability of real estate, industrial construction and infrastructure firms: evidence from India. Journal of Financial Management of Property and Construction, 25(2).

Dalci, I. (2018). Impact of financial leverage on profitability of listed manufacturing firms in China. Pacific Accounting Review, 30(4), 410-432.

Dong, H. P., \& Su, J. T. (2010). The relationship between working capital management and profitability: a Vietnam case. International Research Journal of Finance and Economics, 49(1), 59-67.

Eljelly, A. M. (2004). Liquidity-profitability tradeoff: An empirical investigation in an emerging market. International journal of commerce and management, 14(2), 48-61.

Gill, A., Biger, N., \& Mathur, N. (2010). The relationship between working capital management and profitability: Evidence from the United States. Business and Economics Journal, 10(1), 1-9.

Hanafi, S. M. (2011). Perbandingan kriteria syariah pada indeks saham syariah Indonesia, Malaysia, dan Dow Jones. Asy-Syir'ah Jurnal Ilmu Syariah dan Hukum, 45(11).

Hassan, M. K., Aliyu, S., Saiti, B., \& Halim, Z. A. (2020). A review of Islamic stock market, growth and real-estate finance literature. International Journal of Emerging Markets.

Kasmir. (2013). Analisis Laporan Keuangan Cetakan Keenam. Jakarta (ID), PT. Raja Grafindo Persada.

Lazaridis, I. \& Tryfonidis, D. (2006). Relationship between working capital management and profitability of listed companies in the Athens stock exchange. Journal of Financial Management and analysis, 19(1), 26-35.

Malik, H. (2011). Determinants of insurance companies profitability: an analysis of insurance sector of Pakistan. Academic Research International, 1(3), 315-321.

Modigliani, F. \& Miller, M, H. (1958). The cost of capital, corporation finance, and the theory of Investment. The American Economic Review, 48(3), 261-297.

Nanda, S., \& Panda, A. K. (2018). The determinants of corporate profitability: An investigation of Indian manufacturing firms. International Journal of Emerging Markets, 13(1).

Orhun, E. (2021). The impact of COVID-19 global health crisis on stock markets and understanding the cross-country effects. Pacific Accounting Review, 33(1).

Pindyck, R.S. and Rubinfield, D.L. (1998). Econometric Models and Economic Forecast, Fourth Edition. New York (US), McGraw Hill.

Salike, N. \& Ao, B. (2018). Determinants of bank's profitability: role of poor asset quality in Asia. China Finance Review International, 8(2).

Supriatna, A. \& Wardana, A. (2020). Pengaruh net working capital dan debt to equity ratio terhadap return on equity pada pt astra international tbk. Jurnal Disrupsi Bisnis, 3(2), 205-222.

Tyagi, S. \& Nauriyal, D.K. (2017). Firm level profitability determinants in Indian drugs and pharmaceutical industry. International Journal of Pharmaceutical and Healthcare Marketing, 11(3).

Wooldridge, J.M.. (2001). Econometric Analysis of Cross Section and Panel Data, Second Edition. London (UK), MIT Press.

Yazdanfar, D. (2013). Profitability determinants among micro firms: evidence from Swedish data. International Journal of Managerial Finance, 9(2). 